\title{
Wind energy resource assessment of desert sites in Algeria: energy and reduction of $\mathrm{CO}_{2}$ emissions
}

\author{
Miloud Benmedjahed, Rachid Maouedj, Samir Mouhadjer \\ Unité de Recherche en Energies Renouvelables en Milieu Saharien (URERMS), \\ Centre de Développement des Energies Renouvelables, Alegria
}

\begin{tabular}{l}
\hline Article Info \\
\hline Article history: \\
Received Mar 24, 2019 \\
Revised Oct 14, 2019 \\
Accepted Feb 19, 2020 \\
\hline
\end{tabular}

Keywords:

Algeria

Carbon

Energy

Weibull

Wind

\begin{abstract}
This paper presents a statistical analysis of wind potential of four locations in southern Algeria, namely Adrar, In Salah, Illizi and Tamanrasset, using the Weibull distribution. The evaluation the energy production by the CALORIUS 37 wind turbine taking into account the meteorological (wind and temperature and geographical (latitude, longitude and altitude) datas of these locations. The data were collected every 3 hours over 5 years and used to estimate of the annual energy produced, in order to determine the amount of three types of fossil energy (natural gas, gasoil and gasoline) preserved and the quantities of $\mathrm{CO}_{2}$ that can be avoided. The shape parameter $\mathrm{k}$, varies from 2.0 (Illizi and Tamanrasset) to 2.48 (In Salah), this means that all the distributions are stable, while the scale parameters $\mathrm{C}$ varies from 4.6 $\mathrm{m} / \mathrm{s}$ (Illizi) to $6.3 \mathrm{~m} / \mathrm{s}$ (In Salah) and mean velocity v varies from $4.1 \mathrm{~m} / \mathrm{s}$ (Illizi) to $5.5 \mathrm{~m} / \mathrm{s}$ (Adrar), while the annual energy produced by CALORIUS 37 range from $4467.6 \mathrm{kWh}$ (Illizi) to $8409.6 \mathrm{kWh}$ (Adrar), the equivalent of energies range from 0.38 TEP (Illizi) to 0.72 TEP (Adrar) and the amount of carbon dioxide $\left(\mathrm{CO}_{2}\right)$ that we can provide varies from $0.90 \mathrm{TE}-\mathrm{CO}_{2}$ (natural gas power plant in Illizi ) to $2.24 \mathrm{TE}-\mathrm{CO}_{2}$ (gasoil power plant in Adrar).
\end{abstract}

This is an open access article under the CC BY-SA license.

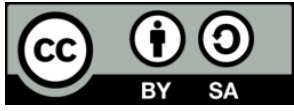

\section{Corresponding Author:}

Miloud Benmedjahed,

Unité de Recherche en Energies Renouvelables en Milieu Saharien (URERMS),

Centre de Développement des Energies Renouvelables,

CDER, 01000, Adrar, Alegria.

Email:m_benmedjahed@urerms.dz

\section{INTRODUCTION}

The high consumption of fossil fuels has released into the atmosphere for two centuries, very large quantities of carbon dioxide from the carbon accumulated in the subsoil since the Paleozoic [1]. The resulting increase in atmospheric $\mathrm{CO}_{2}$ concentration is the main factor of global warming [2]. In 2007, the Intergovernmental Panel on Climate Change (IPCC) states that human activities are responsible for climate change with a very high degree of confidence (= about $90 \%$ probability) [3]; In 2014, the IPCC also published a report classifying sources of electricity production based on their greenhouse gas emissions [4].

Greenhouse gases (GHGs) are a problem. They are gaseous components that absorb infrared radiation from the Earth's surface and contribute to the greenhouse effect. Increasing its concentration in the Earth's atmosphere is one of the greenhouse agents [5-8]. For the whole period 1960-2014, Algeria records an annual average of 65903.46 tons of $\mathrm{CO}_{2}$ [9]. The change between the first and last year is $2260 \%$. The highest value was recorded in 2014 (145400.22 tons) [10] and the lowest value was recorded in 1963 (5427.16 tons), the value estimate that 2020 is about 171022 tones [11]. 
This forecast has a very high level of reliability since the variations of the last five available values have a very linear structure (correlation coefficient equal to 0.97) [12]. In the short term, we have inexhaustible renewable energy resources, which we can exploit more and more easily and cleanly. Nevertheless, neglected for a long time, the techniques of extracting the power of these resources call for more in-depth research and development aimed at making them more reliable, lowering costs (for manufacturing, use and recycling) and increasing energy efficiency [13, 14].

Renewable energies are energy sources that use natural resources considered inexhaustible (wind, sun, tides, waterfalls, earth, plants.....) it is the only solution; these energies do not produce greenhouse gases, and the discharge of pollutants, and do not generate or waste little waste. They do not use the planet's fossil resources, such as natural gas or oil, whose reserves are declining [15, 16]. Algeria is committed to renewable energies to protect the environment while reducing reliance on fossil fuels, this strategic choice is motivated by the huge potential in solar energy. This energy constitutes the major axis of the program which devotes to thermal solar and solar photovoltaic an essential part [17-19].

Solar energy is expected to reach more than $37 \%$ of national electricity generation by 2030 ; this program does not exclude wind power which is the second axis of development and whose share should be around $3 \%$ of electricity production in 2030 [20]. The study of the wind potential is important in order to locate the site of settlements for the future wind development zone, the estimate of the wind potential in Algeria has shown that, the Mediterranean region characterized by a low wind speed, but the Sahara region is windy [21-30].

The present study attempts to evaluate wind potential of four locations in southern Algeria. The evaluation the energy production by the CALORIUS 37 wind turbine taking into account the meteorological (wind and temperature and geographical (latitude, longitude and altitude) datas of these locations. The data were collected every 3 hours over 5 years and used to estimate of the annual energy produced, in order to determine the amount of three types of fossil energy (natural gas, gasoil and gasoline) preserved and the quantities of $\mathrm{CO}_{2}$ that can be avoided.

\section{WIND DATA}

Explaining research chronological, including research design, research procedure (in the form of algorithms, pseudocode or other), how to test and data acquisition [1-3]. The description of the course of research should be supported references, so the explanation can be accepted scientifically [2, 4]. From the wind data collected in the meteorological stations of the sites studied, we mainly focused on annual average wind speeds at $10 \mathrm{~m}$ from the ground. The statistical study is based on the processing of collected data every 3 hours, during the last 5 years for the selected sites. The statistical distribution of Weibull is appropriate for the study of the wind speeds distribution, this distribution function can be written as follows [31-44]:

$$
f(v)=\frac{k}{C}\left(\frac{v}{c}\right)^{k-1} \exp \left(-\left(\frac{v}{C}\right)^{k}\right)
$$

The shape parameter $\mathrm{k}$ characterizes the distribution symmetry and the scale parameter $\mathrm{C}$ is very close to the mean wind speed, in order to determine the two parameters $\mathrm{k}$ and $\mathrm{C}$, the standard deviation method has been used to determine thes parameters as shown in (2) and (3) [37].

$$
\begin{aligned}
& k=\left(\frac{\sigma_{v}}{\bar{v}}\right)^{1.09} \\
& C=\frac{\bar{v}}{\Gamma\left(1+\frac{1}{k}\right)}
\end{aligned}
$$

Weibull parameters and mean velocity were calculated for the four sites studied at $10 \mathrm{~m}$ from the ground as shown in Table 1. From table, It can be observed that the values of the shape parameter k, varies from 2.0 (Illizi and Tamanrasset) to 2.48 (In Salah), this means that all the distributions are stable, while the scale parameters $C$ varies by $4.6 \mathrm{~m} / \mathrm{s}$ (Illizi) at $6.3 \mathrm{~m} / \mathrm{s}$ (Adrar) and mean velocity v varies from $4.1 \mathrm{~m} / \mathrm{s}$ (Illizi) to $5.5 \mathrm{~m} / \mathrm{s}$ (Adrar). If we refer to the classification of the national physical laboratory NLP,

\footnotetext{
Wind energy resource assessment of desert sites in Algeria; energy and reduction ... (Miloud Benmedjahed)
} 
we note that In Salah is considered a favorable area for the development of wind energy, it is in class (03), so the region of Adar is in the class (04), he also found appropriate wind turbine explosion, for the other two sites the wind speed is weak to install a wind farm.

Table 1 . Weibull parameters and mean velocity at $10 \mathrm{~m}$ from the ground (collected data every 3 hours over 5 years)

\begin{tabular}{cccc}
\hline Site & $\mathrm{C}(\mathrm{m} / \mathrm{s})$ & $\mathrm{k}$ & $\overline{\mathrm{v}}(\mathrm{m} / \mathrm{s})$ \\
\hline Adrar & 6.3 & 2.12 & 5.5 \\
In Salah & 6 & 2.48 & 5.3 \\
Illizi & 4.6 & 2.00 & 4.1 \\
Tamanrasset & 5.1 & 2.00 & 4.5 \\
\hline
\end{tabular}

\section{WIND ENERGY}

\subsection{Power}

The wind power relation for wind speeds v, section $S$ and air density $\rho$ is expressed by (4) [45-50]:

$$
P(v)=\frac{1}{2} \rho S v^{3}
$$

The reference air density $\left(1.225 \mathrm{~kg} / \mathrm{m}^{3}\right)$ corresponds to the density of air at sea level (for the temperature of $15^{\circ} \mathrm{C}$ and the pressure $\mathrm{P}=1013.3 \mathrm{mbar}$ ), is used in the power curves for the manufacturers of the wind turbines, but the air density is a local parameter, where it depends on atmospheric pressure and temperature at each location. Assuming that air is a perfect gas we can conclude the following report [37]:

$$
\rho=\frac{335.49}{T} \exp \left(-0.034 \frac{Z}{T}\right)
$$

where $\mathrm{Z}$ is the altitude $(\mathrm{m})$ and $\mathrm{T}$ is the temperature $\left({ }^{\circ} \mathrm{k}\right)$.

The wind speed data are measured at a height of $10 \mathrm{~m}$, while the wind speed changes with the heights. The extrapolation expression of the Weibull parameters is used to extrapolate the parameters $\mathrm{k}_{1}, \mathrm{C}_{1}$ from reference height $\mathrm{Z}_{1}$ to the parameters $\mathrm{k}_{2}, \mathrm{C}_{2}$ at the hub height $\mathrm{Z}_{2}$, which can be expressed by (6-8) [51].

$$
\begin{aligned}
& \frac{k_{2}}{k_{1}}=\left[\frac{1-0.08881 \ln \left(\frac{Z_{1}}{10}\right)}{1-0.08881 \ln \left(\frac{Z_{2}}{10}\right)}\right] \\
& \frac{C_{2}}{C_{1}}=\left(\frac{Z_{2}}{Z_{1}}\right)^{\alpha}
\end{aligned}
$$

with

$$
\alpha=\left[\frac{0.37-0.08881 \ln \left(C_{1}\right)}{1-0.08881 \ln \left(\frac{Z_{1}}{10}\right)}\right]
$$

The wind turbine can convert wind aerodynamic energy into electrical energy, where the wind electric power can be written in (9) [38].

$$
p_{e}(v)=C_{e}(v) p(v)
$$


The coefficient of efficiency of the wind turbine Ce can be written in the form of a polynomial $[23,24,38]$ :

$$
\left\{\begin{array}{lll}
C_{e}(v)=\sum_{i=0}^{6} a_{i} v^{i} & \text { if } & v_{d} \leq v \leq v_{a} \\
C_{e}(v)=0 & \text { if } & v_{d}>v \quad \text { or } \quad v>v_{a}
\end{array}\right.
$$

where $\mathrm{v}_{\mathrm{d}}$ is cut-in wind speed $(\mathrm{m} / \mathrm{s})$ and $\mathrm{v}_{\mathrm{a}}$ is cut-out wind speed $(\mathrm{m} / \mathrm{s})$.

The wind turbine parameters of stander model are listed in the Table 2 and the power output curves for the reference air density presented in Figure 1. From Figure 2, it can be observed that the annual average power range from $0.51 \mathrm{~kW}$ (Illizi) to $0.96 \mathrm{~kW}$ (Adrar), we noticed that the average power depended to the wind turbine diameter and climatic conditions (wind speed and temperature) as well as the efficiency of this the wind turbine. The power curve $(\mathrm{kW})$ was superimposed on the frequency Weibull curve $\mathrm{H}(\mathrm{v})(\%)$ to evaluate the average power produced by a wind turbine, show in $(11)[38,52]$ :

$$
\bar{P}=\sum_{v_{i}=v_{d}}^{v_{a}} P_{i}\left(v_{i}\right) H_{i}\left(v_{i}\right)
$$

Table 2. Wind turbine parameters [53]

\begin{tabular}{cccccc}
\hline Name & $\mathrm{P}_{\mathrm{r}}(\mathrm{kW})$ & $\mathrm{D}(\mathrm{m})$ & $\mathrm{Z}_{2}(\mathrm{~m})$ & $\mathrm{v}_{\mathrm{d}}(\mathrm{m} / \mathrm{s})$ & $\mathrm{v}_{\mathrm{a}}(\mathrm{m} / \mathrm{s})$ \\
\hline CALORIUS 37 & 5 & 5 & 15 & 3.5 & 20 \\
\hline
\end{tabular}

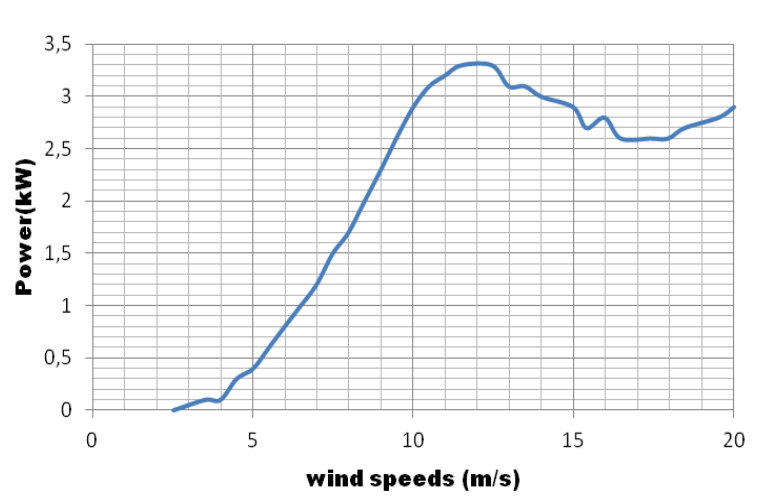

Figure 1. CALORIUS 37 powers curves [53]

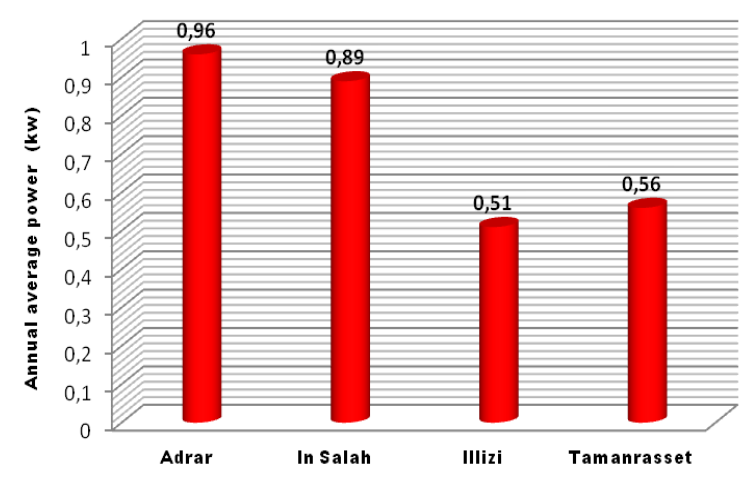

Figure 2. Average of power produced by CALORIUS 37

\subsection{Energy}

The energy produced by a wind turbine for $\mathrm{N}$ hour in one years is calculated by (12) [38]:

$$
E_{w}=N \times \bar{P}
$$

From Table 3, it can be said that the annual energy produced by CALORIUS 37 range from 4467.6 $\mathrm{kWh}$ (Illizi) to $8409.6 \mathrm{kWh}$ (Adrar), the equivalent of energies which vary from 0.38 TEP (Illizi) to 0.72 TEP (Adrar). This means that using a one turbine for one year will save about $803369.09 \mathrm{~m}^{3}$ of natural gas or 0.71 ton of gasoil or 0.69 tones of gasoline at Adrar; for In Salah, we can do without $744790.09 \mathrm{~m}^{3}$ of natural gas 0.66 tons of gasoil or 0.64 tons of gasoline, in Tamanrasset can save $468631.97 \mathrm{~m}^{3}$ of natural gas or 0.42 tons of gasoil or 0.40 tons of gasoline; finally, we can win $426789.83 \mathrm{~m}^{3}$ of natural gas or 0.38 tons of the gasoil or 0.36 tons of the gasoline in Illizi. From Figure 3, it can be said that the amount of carbon dioxide $\left(\mathrm{CO}_{2}\right)$ that we can provide varies from $0.90 \quad \mathrm{TE}_{-} \mathrm{CO}_{2}$ (Natural gas power plant in Illizi ) to 2.24 TE- $\mathrm{CO}_{2}$ (gasoil power plant in Adrar). 
Table 3. The annual energy produced by CALORIUS 37 and its fossil fuel equivalence

\begin{tabular}{ccccc}
\hline Energy & Adrar & Salah & Illizi & Tamanrasset \\
\hline Energy (kwh) & 8409.6 & 7796.4 & 4467.6 & 4905.6 \\
Energy (TEP) & 0.72 & 0.67 & 0.38 & 0.42 \\
Natural Gaz (m ${ }^{3}$ ) & $8.03 \mathrm{E} 05$ & $7.48 \mathrm{E} 05$ & $4.27 \mathrm{E} 05$ & $4.69 \mathrm{E} 05$ \\
Gasoil (ton) & 0.71 & 0.66 & 0.38 & 0.42 \\
Gasoline (ton) & 0.69 & 0.64 & 0.36 & 0.40 \\
\hline
\end{tabular}

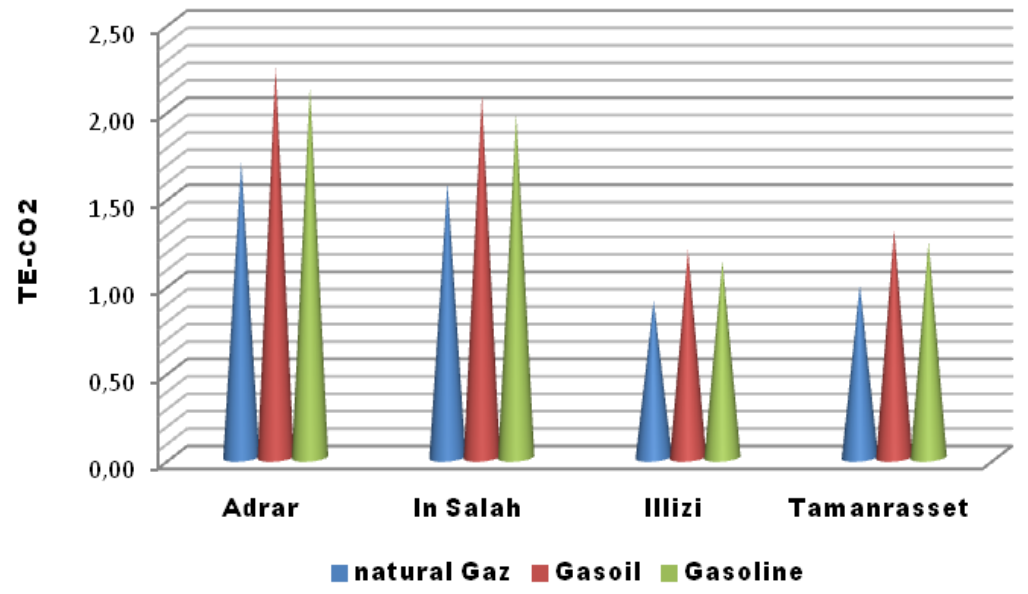

Figure 3. The amount of carbon dioxide $\left(\mathrm{CO}_{2}\right)$

\section{CONCLUSION}

This study focused on the evaluation of the wind potential and energy produced by small wind turbine in Algerian Sahara. The results obtained are: (a) The shape parameter k, varies from 2.0 (Illizi and Tamanrasset) to 2.48 (In Salah), this means that all the distributions are stable, while the scale parameters C varies by $4.6 \mathrm{~m} / \mathrm{s}$ (Illizi) at $6.3 \mathrm{~m} / \mathrm{s}$ (Adrar) and mean velocity v varies from $4.1 \mathrm{~m} / \mathrm{s}$ (Illizi) to $5.5 \mathrm{~m} / \mathrm{s}$ (Adrar); (b) The annual average power range from $0.51 \mathrm{~kW}$ (Illizi) to $0.96 \mathrm{~kW}$ (Adrar), we noticed that the average power depended to the wind turbine diameter and climatic conditions (wind speed and temperature) as well as the efficiency of this the wind turbine; (c) The annual energy produced by CALORIUS 37 range from $4467.6 \mathrm{kWh}$ (Illizi) to $8409.6 \mathrm{kWh}$ (Adrar), the equivalent of energies which vary from 0.38 TEP (Illizi) to 0.72 TEP ( Adrar); (d) The amount of carbon dioxide $\left(\mathrm{CO}_{2}\right)$ that we can provide varies from $0.90 \mathrm{TE}-\mathrm{CO}_{2}$ (Natural gas power plant in Illizi ) to $2.24 \mathrm{TE}-\mathrm{CO}_{2}$ (gasoil power plant in Adrar).

\section{REFERENCES}

[1] "Qu'est-ce que l'effet de serre? - Jean-Marc Jancovici." [Online]. Available: https://jancovici.com/changementclimatique/aspects-physiques/quest-ce-que-leffet-de-serre/. [Accessed: 26-Dec-2018].

[2] A. Othmani, et al, "Evaluation de l'impact du parc éolien de Kaberten à Adrar sur l'environnement," Thesis, Université Ahmed Draïa Adrar, 2019.

[3] I. P. on C. C. W. G. I, G. d'experts intergourvernemental sur l'évolution du climat W. G. II, et I. P. on C. Change, "Climate change 2007 - impacts, adaptation and vulnerability: working group ii contribution to the fourth assessment report of the IPCC." Cambridge University Press, 2007.

[4] R. K. Pachauri et al., "Climate change 2014: synthesis report. Contribution of working groups i, ii and iii to the fifth assessment report of the intergovernmental panel on climate change," IPCC, 2014.

[5] W. D. Nordhaus, "To slow or not to slow: the economics of the greenhouse effect," Econ. J., vol. 101, no 407, pp. 920-937, 1991.

[6] M. Meinshausen et al., "Greenhouse-gas emission targets for limiting global warming to $2^{\circ} \mathrm{C}$,", Nature, vol. 458 , no. 7242 , pp. 1158-1162, 2009.

[7] T. Wheeler and J. von Braun, "Climate change impacts on global food security," Science, vol. 341, no. 6145, pp. 508-513, 2013.

[8] K. M. Shea et al., "Climate change and allergic disease," J. Allergy Clin. Immunol, vol. 122, no. 3, pp. 443-453, 2008. 
[9] I. Mokrani, "Réduction des émissions de gaz à effet de serre: plusieurs efforts engagés par l'Algérie." [Online]. Available: http://www.aps.dz/economie/69535-reduction-des-emissions-de-gaz-a-effet-de-serre-plusieurs-effortsengages-par-1-algerie. [Accessed: 26-Dec-2018].

[10] A. Boualem, "Reporters - Réduction des gaz à effet de serre: Les engagements d'Alger". [Online]. Available: http://www.reporters.dz/index.php/rss-a-la-une/item/55349-reduction-des-gaz-a-effet-de-serre-les-engagements-dalger. [Accessed: 26-Dec-2018].

[11] J. Rutqvist, D. W.Vasco and L. Myer, "Coupled reservoir-geomechanical analysis of $\mathrm{CO}_{2}$ injection and ground deformations at In Salah, Algeria,” Int. J. Greenh. Gas Control, vol. 4, no. 2, pp. 225-230, 2010.

[12] A. Mathieson, et al. "CO2 sequestration monitoring and verification technologies applied at Krechba, Algeria," Lead. Edge, vol. 29, no. 2, pp. 216-222, 2010.

[13] A. Hobson, "Resource letter PSEn-1: physics and society: energy," Am. J. Phys., vol. 75, no. 4, pp. 294-308, 2007.

[14] I. Strauch and B. Meier, "In search of dreams: results of experimental dream research," SUNY Press, 1996.

[15] D. Infield, and L. Freris "Renewable energy in power systems," John Wiley \& Sons, 2020.

[16] J. Twidell et al., "Renewable energy resources," Routledge, 2015.

[17] K. Kaygusuz, "Energy for sustainable development: a case of developing countries," Renew. Sustain. Energy Rev., vol. 16, no 2, pp. 1116-1126, 2012.

[18] T. eddine Boukelia and M.-S. Mecibah, "Parabolic trough solar thermal power plant: potential, and projects development in Algeria," Renew. Sustain. Energy Rev., vol. 21, pp. 288-297, may 2013.

[19] R. Saidur et al., "A review on global wind energy policy," Renew. Sustain. Energy Rev., vol. 14, no. 7, pp. 1744-1762, 2010.

[20] M. Benmedjahed, "Choix du site et optimisation du dimensionnement d'une installation éolienne dans le nord Algérien et son impact sur l'environnement," Thesis, 2014.

[21] F. Chellali et al., "A contribution in the actualization of wind map of Algeria," Renew. Sustain. Energy Rev., vol. 15, no. 2, pp. 993-1002, 2011.

[22] R. Saidur et al., "A review on global wind energy policy," Renew. Sustain. Energy Rev., vol. 14, no. 7, pp. 1744-1762, 2010.

[23] M. Benmedjahed et al., "Assessment of wind energy and energy cost in Algeria," J. Renew. Energy Smart Grid Technol., vol. 9, no. 1, pp. 31-40, 2014.

[24] M. Benmemdejahed and S. Mouhadjer, "Evaluation of wind energy cost and site selection for a wind-farm in the south of Algeria," AIP Conf. Proc., vol. 1758, no. 1, pp. 030001, 2016.

[25] M. Benmedjahed and R. Maouedj, "L’impacte d'un parc éolien sur l'environnement au sud Algérien," Editions universitaires europeennes, 2017.

[26] Y. Himri et al., "Review and use of the Algerian renewable energy for sustainable development," Renew. Sustain. Energy Rev., vol. 13, no. 6, pp. 1584-1591, 2009.

[27] S. M. Boudia et al., "Temporal assessment of wind energy resource at four locations in Algerian Sahara," Energy Convers. Manag. vol. 76, pp. 654-664, 2013.

[28] M. Benmedjahed, et al., "Temporal Assessment of Wind Energy Resource in "Adrar" (South of Algeria); Calculation and Modeling of Wind Turbine Noise," in 2nd International Congress on Energy Efficiency and Energy Related Materials (ENEFM2014), 2015, pp. 3342.

[29] M. Benmedjahed and R. Maouedj, "The wind farm impact on the environment in Tindouf," LAP LAMBERT Academic Publishing, 2017.

[30] N. K. Merzouk, "Wind energy potential of Algeria," Renew. Energy, vol. 21, no. 3, pp. 553-562, 2000.

[31] I. Y. F. Lun and J. C. Lam, "A study of Weibull parameters using long-term wind observations," Renew. Energy, vol. 20, no. 2, pp. 145-153, 2000.

[32] D. Weisser, "A wind energy analysis of Grenada: an estimation using the "Weibull' density function," Renew. Energy, vol. 28, no. 11, pp. 1803-1812, 2003.

[33] M. R. Islam et al., "Assessment of wind energy potentiality at Kudat and Labuan, Malaysia using Weibull distribution function," Energy, vol. 36, no. 2, pp. 985-992, 2011.

[34] C. G. Justus et al., "Methods for estimating wind speed frequency distributions," J. Appl. Meteorol., vol. 17, no. 3, pp. $350-353,1978$.

[35] J. V. Seguro and T. W. Lambert, "Modern estimation of the parameters of the Weibull wind speed distribution for wind energy analysis," J. Wind Eng. Ind. Aerodyn., vol. 85, no. 1, pp. 75-84, 2000.

[36] M. Benmedjahed and L. Boudaoud, "Temporal Assessment of Wind Energy Resource in Algerian Desert Sites: Calculation and Modelling of Wind Noise," J. Fundam. Renew. Energy Appl., vol. 5, no. 3, pp.1-4, 2015.

[37] S. Mathew, "Wind energy: fundamentals, resource analysis and economics," 2007.

[38] M. Benmedjahed et al., "Wind potential assessment of ain salah in Algeria; calculation of the cost energy," Int. J. Energy Power Eng., vol. 4, no. 2, pp. 38, 2015.

[39] R. Maouedj et al., "Evaluation of the wind energy potential in the Saharan sites of Algeria," in 2011 10th International Conference on Environment and Electrical Engineering, pp. 1-4, 2011.

[40] R. Maouedj et al., "Evaluation of the wind energy potential in the Saharan sites of Algeria," in 2011 10th International Conference on Environment and Electrical Engineering, pp. 1-4, 2011.

[41] M. Benmedjahed and R. Maouedj, "Technical and Economic Analysis of Wind Turbine System for Isolated Location at Adrar in Algeria," 2018 6th International Renewable and Sustainable Energy Conference (IRSEC), Rabat, Morocco, 2018, pp. 1-4. 
[42] R. Maouedj et al., "Wind characteristics analysis for selected site in Algeria," Int. J. Comput. Appl., vol. 56, no. 5, pp. 39-46, 2012.

[43] R. Maouedj et al., "Wind energy resource assessment at three sites in the algerian highlands," in 20186 th International Renewable and Sustainable Energy Conference (IRSEC), pp. 1-6, 2018.

[44] M. Benmedjahed and R. Maouedj, "Wind power assessment in algeria; methods development," in 2018 International Conference on Wind Energy and Applications in Algeria (ICWEAA), pp. 1-6, 2018.

[45] J. A. Carta et al., "A review of wind speed probability distributions used in wind energy analysis: Case studies in the Canary Islands," Renew. Sustain. Energy Rev., vol. 13, no. 5, pp. 933-955, 2009.

[46] M. Chinchilla, et al., "Control of permanent-magnet generators applied to variable-speed wind-energy systems connected to the grid," IEEE Trans. Energy Convers., vol. 21, no. 1, pp. 130-135, 2006.

[47] K. E. Johnson, et al., "Control of variable-speed wind turbines: standard and adaptive techniques for maximizing energy capture," IEEE Control Syst. Mag., vol. 26, no. 3, pp. 70-81, 2006.

[48] B. S. Borowy and Z. M. Salameh, "Dynamic response of a stand-alone wind energy conversion system with battery energy storage to a wind gust," IEEE Trans. Energy Convers., vol. 12, no. 1, pp. 73-78, 1997.

[49] A. S. Ahmed Shata and R. Hanitsch, "Evaluation of wind energy potential and electricity generation on the coast of Mediterranean Sea in Egypt," Renew. Energy, vol. 31, no. 8, pp. 1183-1202, 2006.

[50] S.D. Kwon, "Uncertainty analysis of wind energy potential assessment," Appl. Energy, vol. 87, no. 3, pp. 856-865, 2010.

[51] C. G. Justus and A. Mikhail, "Height variation of wind speed and wind distributions statistics," Geophys. Res. Lett., vol. 3, no. 5, pp. 261-264, 1976.

[52] K. S. Kadali and L. Rajaji, "Evaluation of Energy in Wind Turbine System Using Probability Distribution," Indonesian Journal of Electrical Engineering and Computer Science, vol. 9, no. 2, pp. 294-298, 2018.

[53] "EMD International A/S Downloads - EMD International A/S." [Online]. Available: https://www.emd.dk /windpro/downloads/. [Accessed: 15-Apr-2019]. 